\title{
Frequency of the C677T variant of the methylenetetrahydrofolate reductase (MTHFR) gene in patients with migraine with or without aura - a preliminary report
}

\author{
Częstość występowania wariantu C677T genu MTHFR u pacjentów z migrenq z aurq \\ i bez aury - doniesienie wstępne
}

Dorota Szzzygioł', Ewa Motta', Anna Gołba', Arkadiusz Stęposz', Joanna Witecka², Marek Dębski', Daria Błaszkiewicz', Aleksander Sieroń

1Oddział Neurologii SPSK nr 7, Śląski Uniwersytet Medyczny w Katowicach

2Katedra i Zakład Biologii Ogólnej, Molekularnej i Genetyki, Śląsi Uniwersyytet Medyczny w Katowicach

Neurologia i Neurochirurgia Polska 2012; 46, 5: 443-449

D01: 10.5114/ninp.2012.31354

\begin{abstract}
Background and purpose: The aim of our study was to evaluate the frequency of the $\mathrm{C} 677 \mathrm{~T}$ variant in the methylenetetrahydrofolate reductase $(M T H F R)$ gene in patients with migraine with or without aura and to find an association between this variant and vascular lesions in magnetic resonance imaging of the head, presence of patent foramen ovale (PFO) and increased level of homocysteine.
\end{abstract}

Material and methods: Ninety-one patients with migraine, aged 19-57, were investigated in this study. The MTHFR $\mathrm{C} 677 \mathrm{~T}$ variant was genotyped in this group and levels of homocysteine, folic acid and vitamin $\mathrm{B}_{12}$ were measured. Transcranial Doppler sonography with test for PFO detection by injection of air contrast during the Valsalva manoeuvre was performed in each patient.

Results: Frequency of the C677T variant in the MTHFR gene was similar in patients and controls. Hyperhomocysteinaemia was significantly more frequent in migraine patients with the C677T variant. The prevalence of $\mathrm{PFO}$ was significantly higher in migraine patients with aura and the homozygous variant of the MTHFR gene.

Conclusions: Frequency of the C677T variant in the MTHFR gene was similar in patients and controls. Significantly more

\section{Streszczenie}

Wstęp i cel pracy: Celem pracy była ocena częstości występowania wariantu C677T genu MTHFR u chorych na migrenę oraz określenie, czy istnieje związek pomiędzy wariantem genu a stężeniem homocysteiny w surowicy, obecnością ogniskowych zmian naczyniopochodnych w badaniu za pomoca rezonansu magnetycznego (RM) głowy oraz występowaniem drożnego otworu owalnego.

Materiał i metody: Badaniem objęto 91 chorych. U wszystkich wykonano rutynowe badanie neurologiczne i internistyczne, oznaczenia stężenia witaminy $\mathrm{B}_{12}$, kwasu foliowego i homocysteiny w surowicy, badanie na obecność wariantu C677T genu MTHFR, badanie dopplerowskie tętnic mózgowych z podaniem kontrastu celem diagnostyki drożnego otworu owalnego, a także RM głowy.

Wyniki: Częstość występowania wariantu C677T genu MTHFR była podobna u osób z migreną i w grupie kontrolnej. Zwiększone stężenie homocysteiny w surowicy obserwowano znamiennie częściej u chorych na migrenę, u których stwierdzono obecność wariantu C677T genu MTHFR. Drożny otwór owalny występował znamiennie częściej u chorych na migrenę z aurą, u których stwierdzono obecność homozygoty wariantu C677T genu MTHFR.

Correspondence address: dr Anna Gołba, Oddział Neurologii SPSK nr 7, Śląski Uniwersytet Medyczny, ul. Ziołowa 45-47, 40-635 Katowice, phone/fax: +4832 20295 92, e-mail: sum.neurologia@op.pl

Received: 10.01.2012; accepted: 20.03.2012 
frequent prevalence of $\mathrm{PFO}$ in migraine patients with aura (with homozygous recessive genotype of $M T H F R$ ) probably suggests their common genetic basis. Hyperhomocysteinaemia was significantly more frequent in migraine patients with the C677T variant, which could be an additional risk factor of this disease.

Key words: migraine, MTHFR gene, patent foramen ovale.

\section{Introduction}

Diagnostic and therapeutic difficulties in some cases of migraine inspire the continued search for new causes and novel treatments for this disease. The significance of genetic factors has been highlighted in recent years, leading to the consideration of migraine as a polygenic disease [1]. Numerous reports show an association between the $\mathrm{C} 677 \mathrm{~T}$ variant of the MTHFR gene (coding methylenetetrahydrofolate reductase) and the prevalence of migraine with aura [2-4]. The impact of the mutations within that gene (especially homozygous form) in hyperhomocysteinaemia, recognized as an independent vascular risk factor, is also stressed $[3,4]$.

The metabolism of homocysteine requires an adequate supply of vitamin $B_{12}$ and folic acid for normal remethylation reaction. Presence of the $\mathrm{C} 677 \mathrm{~T}$ variant of MTHFR decreases the activity of methylenetetrahydrofolate reductase, leading therefore to an increased level of homocysteine [5]. In recent years attention has been drawn to the common mechanism of migraine and persistent foramen ovale (PFO). The coincidence of these two entities may be found in as many as $40 \%$ of patients [6].

The aim of the present study was to evaluate the frequency of the C677T variant of the MTHFR gene in patients with migraine and to find an association between this variant and increased level of homocysteine, presence of vascular lesions in magnetic resonance imaging (MRI) of the head, or presence of PFO.

\section{Material and methods}

The study comprised 91 patients, including 71 women and 20 men, aged between 19 and 57 years (mean
Wnioski: Częstość występowania wariantu C677T genu MTHFR u pacjentów z migreną jest podobna jak u osób bez tej choroby. Znamiennie częstsze występowanie drożnego otworu owalnego u osób z migreną z aurą, u których stwierdzono obecność homozygoty wariantu C677T genu MTHFR, mogłoby sugerować związek tego typu migreny $\mathrm{z}$ anomalią rozwojową serca i ich ewentualne wspólne podłoże genetyczne. Znamiennie częstsze występowanie zwiększonego stężenia homocysteiny w surowicy u pacjentów z migreną, u których stwierdzono obecność wariantu C677T genu MTHFR mogłoby być dodatkowym czynnikiem ryzyka wystąpienia migreny.

Słowa kluczowe: migrena, gen $M T H F R$, drożny otwór owalny.

$38 \pm 10.3$ years), diagnosed with migraine according to the criteria of the International Headache Society [7]. All patients were hospitalized in the Department of Neurology within the Seventh Independent Public Teaching Hospital (Medical University of Silesia) in KatowiceOchojec and were followed up in the outpatient neurological clinic. Fifty-one patients, aged between 22 and 54 years (mean $37.9 \pm 10.2$ years), had migraine with aura, and the other 40 patients, aged between 19 and 57 years (mean $39.2 \pm 10.4$ years), had migraine without aura.

The control group consisted of 48 subjects, including 36 women and 12 men, aged between 24 and 57 (mean $37 \pm 8.6$ years).

All patients with migraine underwent the physical examination (both general and neurological one), along with measurements of serum concentration of vitamin $\mathrm{B}_{12}$, folic acid, and homocysteine. MRI of the head was performed in each patient and the contrast transcranial Doppler study (c-TCD) was used to assess the presence of PFO.

The C677T variant of the MTHFR gene was tested with the polymerase chain reaction (PCR) using restriction enzyme digestion, strictly according to the previously described method [2].

DNA was isolated from whole blood, either fresh or frozen, with the DNA isolation kit Blood Mini (A\&A Biotechnology, Poland). The quantity and quality of the isolated DNA were checked spectrophotometrically (Biomate3 spectrophotometer) at the wavelength of $260 \mathrm{~nm}$ and $280 \mathrm{~nm}$. Purified DNA fragments containing the site of the studied MTHFR variant were amplified by PCR using the PCR primer sequences published by Kowa et al. [8]. The sense primer sequence was 
5'-TGA AGG AGA AGG TGT CTG CGG GA-3', and the antisense primer sequence was 5'-AGG ACG GTG CGG TGA GAG TG-3'.

PCR reaction was performed in a $25-\mu \mathrm{L}$ sample containing $150 \mathrm{ng}$ of genomic DNA, $1 \mathrm{U}$ of Fast Start polymerase (Roche, Germany), $1 \times$ standard PCR buffer with $\mathrm{MgCl}_{2}$, nucleotides mixture at the baseline concentration of $200 \mathrm{mM}$ and distilled water mixed to the final volume of $25 \mu \mathrm{L}$. The following PCR parameters were used: one cycle at $95^{\circ} \mathrm{C}$ for $5 \mathrm{~min}$ for an initial denaturation, followed by 35 cycles of denaturation for $30 \mathrm{~s}$ at $95^{\circ} \mathrm{C}$, primer annealing for $30 \mathrm{~s}$ at $65^{\circ} \mathrm{C}$, primer extension for $30 \mathrm{~s}$ at $72^{\circ} \mathrm{C}$ and a final extension for $5 \mathrm{~min}$ at $72^{\circ} \mathrm{C}$. The mixture was then cooled to $4^{\circ} \mathrm{C}$. This amplification reaction led to the synthesis of a 198-bp fragment. Those fragments were separated using a $1 \%$ agarose gel (Top Vision LE GQ Agarose, Fermentas, USA) with $1 \times$ TAE buffer $(50 \mathrm{X}$ TAE Electrophoresis Buffer, Fermentas, USA). The reaction mixture $(5 \mu \mathrm{L})$ and length marker $(5 \mu \mathrm{L})$ (O'GeneRuler Low Range DNA Ladder, Fermentas, USA) were added to the agarose gel with ethidium bromide. Electrophoretic separation of DNA fragments was visualized under ultraviolet light and the images were captured with a digital camera.

The PCR product mixture (about $0.2 \mu \mathrm{g}$ ) was incubated with 1 IU of HinfI endonuclease (FastDigest Fermentas, USA). FastDigest buffer $(2 \mu \mathrm{L})$ was added to the reaction mixture with distilled water to a final volume of $30 \mu \mathrm{L}$. The reaction mixture was incubated for $5 \mathrm{~min}$ at $37^{\circ} \mathrm{C}$ and then inactivated for $20 \mathrm{~min}$ at $65^{\circ} \mathrm{C}$.

The restriction reaction products were separated using a 2.5\% agarose gel (Top Vision LE GQ Agarose, Fermentas, USA) with $1 \times$ TAE buffer $(50 \mathrm{X}$ TAE Electrophoresis Buffer, Fermentas, USA). The length of the restriction fragments was identified with a length marker $(2 \mu \mathrm{L})$ (O'GeneRuler Low Range DNA Ladder, Fermentas, USA). The $\mathrm{C}$ to $\mathrm{T}$ substitution at nucleotide 677 in the MTHFR gene results in a restriction site for the HinfI enzyme, cleaving this fragment into 175-bp and 23-bp fragments.

TCD was performed in a strictly standardized manner, using the Pioneer TC 2020 (EME) apparatus with $2-\mathrm{MHz}$ and $4-\mathrm{MHz}$ probes [9]. The middle cerebral artery was assessed at the depth of $50-60 \mathrm{~mm}$ with the access through the temporal bony window. TCD technique in search of the $\mathrm{PFO}$ was in accordance with the international consensus [10] with the use of Pioneer TC 2020 (EME) apparatus with dedicated software, enabling simultaneous registration at several depths.
The study was performed in a supine position, with the 18-gauge needle inserted into the right cubital vein. The first stage of testing included bolus injection of the contrast agent produced by vigorous mixing of the normal saline $(9 \mathrm{~mL})$ and air $(1 \mathrm{~mL})$. If no microbubbles were detected within $40 \mathrm{~s}$, the testing was repeated using the Valsalva manoeuvre, increasing the pressure within the thoracic cavity [11]. The third stage of testing (expiration) was made 5 seconds after contrast agent injection. If no embolic signal was detected three times, the study was considered negative. Each patient received a detailed instruction on the appropriate performance during the test, and the efficacy of testing was confirmed by the measured decrease of systolic velocity of the registered blood flow.

A four-grade scale of the right-to-left shunt was used: (1) no microbubbles; (2) 1-10 microbubbles; (3) > 10 microbubbles; and (4) massive microbubbles (so-called 'curtain'). If massive microbubbles were detected, the Valsalva manoeuvre was abandoned. None of the patients reported headache directly after the TCD.

The same panel of tests, with the exception of head MRI and TCD testing for PFO, was performed in controls.

The protocol of the study was approved by the Bioethical Committee of the Medical University of Silesia in June 2009 (L.dz.KNM/0022/KB1/55/I/09).

\section{Statistical analysis}

The database of the clinical material was prepared in Excel 2003 (Microsoft), and the statistical calculations were performed in Statistica v.7.1 (StatSoft) and MedCalc v.9.03. A $p$-value of less than 0.05 was considered statistically significant. The hypothetical distribution conformity of the specific variables with the normal one was tested with the Shapiro-Wilk test.

Unpaired Student's $t$-test was used for comparisons between groups in the case of normally distributed variables. The Mann-Whitney $U$-test was used for non-normally distributed variables. Qualitative variables were compared using the chi-square test with Yates correction.

\section{Results}

The frequency of the C677T variant of the MTHFR gene was similar in patients with migraine and in controls $(47.3 \%$ and $47.9 \%$, respectively; $p=0.94)$. Increas- 
ed serum homocysteine concentration was significantly more prevalent among patients with migraine (regardless of its type) and with the C677T variant of the MTHFR gene than in other migraineurs $(23.8 \%$ vs. $8.3 \%$, respectively; $p=0.04)$. Hyperhomocysteinaemia was similarly prevalent in controls with the $\mathrm{C} 677 \mathrm{~T}$ variant of MTHFR and in those without the C677T variant $(4.3 \%$ vs. $8.0 \%$, respectively; $p=0.6)$.

The prevalence of vascular lesions in MRI in patients with migraine and with the $\mathrm{C} 677 \mathrm{~T}$ variant of the MTHFR gene was similar to the migraineurs without the C677T variant of the MTHFR gene (36.7\% vs. $29.4 \%$, respectively; $p=0.54$ ).

$\mathrm{PFO}$ was found more often in patients with migraine with aura in whom the homozygous C677T variant of the MTHFR gene was found (Fig. 1).

$\mathrm{PFO}$ was found in similar percentages of patients with migraine without aura, in whom the homozygous or heterozygous C677T variant of the MTHFR gene was noted (Fig. 2).

\section{Discussion}

Migraine is a common disease, affecting 10-20\% of the general population, but its pathophysiology is not completely understood. Besides vascular mechanisms, genetic factors probably also play a role. It is believed that the $\mathrm{C} 677 \mathrm{~T}$ variant of the MTHFR gene, as well as polymorphism of the angiotensin-converting enzyme

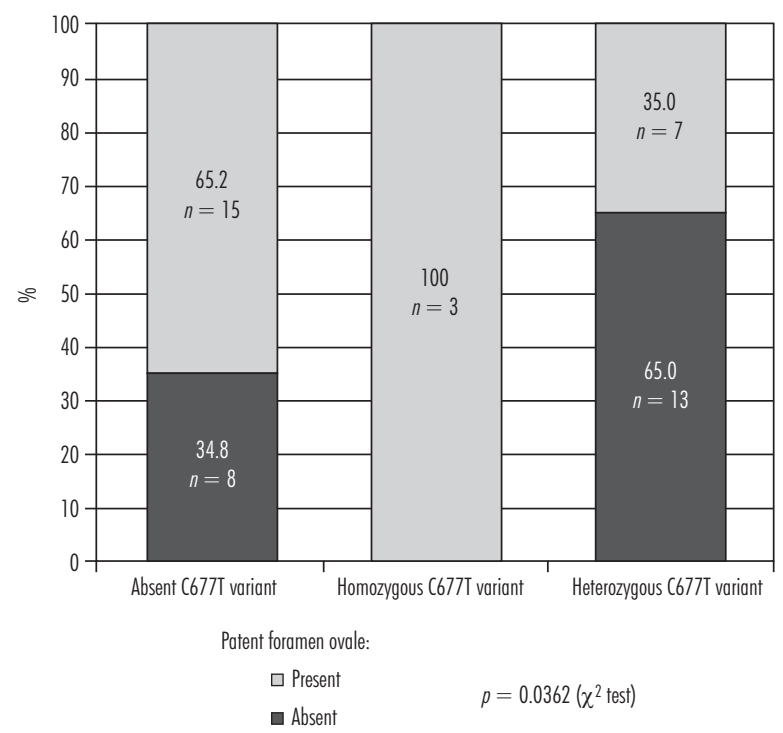

Fig. 1. Prevalence of patent foramen ovale as related to presence of homozygous or heterozygous (677T variant of MTHFR gene in patients with migraine with aura
(ACE) gene, may play an important role in the response to vascular oxidative stress [13]. However, the results of studies on the association between migraine and the $\mathrm{C} 677 \mathrm{~T}$ variant of the MTHFR gene are equivocal $[2,8,14-23]$. Oterino et al. assessed the frequency of the T677 homozygous MTHFR gene in the Spanish population and did not find significant differences between 230 patients with migraine and 204 controls. It was noted only that the $\mathrm{T}$ allele of the MTHFR gene was significantly more frequent in patients with migraine with aura [3]. Finnish studies involving 898 patients with migraine with aura and 900 healthy subjects did not reveal differences in prevalence of $M T H F R$ gene variants between those groups. The authors concluded that the significance of that gene for susceptibility to migraine was unlikely [20]. There was no difference in prevalence of the $\mathrm{C} 677 \mathrm{~T}$ variant of the MTHFR gene between migraineurs and controls in the Portuguese population either [17]. Australian authors studied 267 migraineurs with the $\mathrm{C} 677 \mathrm{~T}$ variant of the MTHFR gene and found that this genotype was associated with specific clinical features of migraine [24].

In 2010 , Schürks et al. reviewed papers reporting genetic studies in migraine published before March 2009. Twelve out of the 21 papers on the C677T variant of the MTHFR gene or ACE D/I polymorphism in various populations were devoted to the $\mathrm{C} 677 \mathrm{~T}$ variant of the MTHFR gene. The combined results of those studies showed that presence of the $\mathrm{T}$ allele was asso-

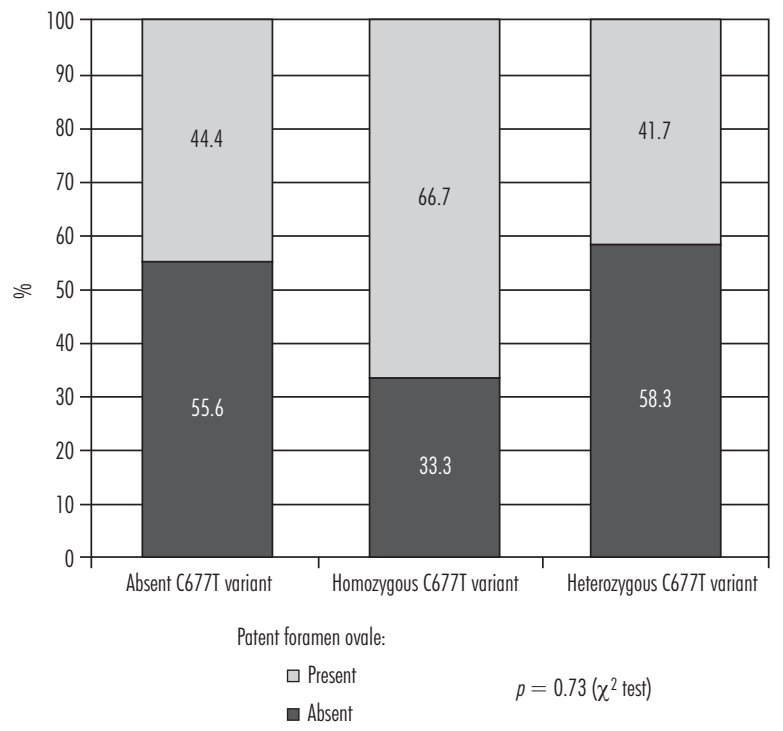

Fig. 2. Prevalence of patent foramen ovale as related to presence of homozygous or heterozygous (677T variant of MTHFR gene in patients with migraine without aura 
ciated with greater risk of migraine development regardless of its type, although the differences were non-significant for the Caucasian population alone. There was no agreement among the analysed studies regarding the probability of development of a particular type of migraine among patients having the $\mathrm{C} 677 \mathrm{~T}$ variant of the MTHFR gene. It was suggested that the presence of that variant increases the risk for migraine with aura but not all studies confirmed that supposition.

TT increases the risk of migraine with aura in the Japanese population but the same genotype increases the risk of migraine without aura in the Turkish population. Such an association was not confirmed in Caucasians. Schürks et al. explain divergent results of the analysed studies with the biological heterogeneity of migraine, different methods of its diagnosis and divergent populations of patients [25].

The current study did not reveal significant differences in prevalence of the $\mathrm{C} 677 \mathrm{~T}$ variant of the MTHFR gene between patients with migraine and controls. This finding might be explained by the relatively small studied samples. Thus, a study on larger groups is required to find potential differences in the Polish population.

Hyperhomocysteinaemia, being one of the vascular risk factors, might also play a role in a pathomechanism of migraine. The endothelial damage caused by homocysteine impairs the release of nitric oxide, and the decreased bioavailability of nitric oxide may result in abnormal reactions between the vessel wall, platelets and macrophages, changing the coagulative properties of blood and affecting the neurovascular functions [26].

The reports on the significance of homocysteine in the migraine pathomechanism are equivocal. Israeli authors studied serum concentration of homocysteine in 78 migraineurs and 126 healthy subjects and found significantly increased homocysteine concentration in one patient only [27]. Scher and colleagues think that the risk of migraine with aura is associated with homozygosity in the $\mathrm{C} 677 \mathrm{~T}$ variant of the MTHFR gene independently of other vascular risk factors [22]. On the other hand, de Tommaso et al. [14] believe that hyperhomocysteinaemia might promote neuronal factors predisposing to the development of migraine.

The most recent study by Oterino et al. [28], performed among 228 patients with migraine with aura, 199 patients with migraine without aura and in 310 controls, showed that patients with migraine with aura had significantly greater serum concentration of homocysteine, and that the $\mathrm{C} 677 \mathrm{~T}$ variant of the MTHFR gene was the best genetic indicator of homocysteine concentration.
Our study showed that hyperhomocysteinaemia was more common in migraineurs with the $\mathrm{C} 677 \mathrm{~T}$ variant of the MTHFR gene (particularly in homozygous patients), which might suggest the possible increased risk of migraine in patients with confirmed hyperhomocysteinaemia and with the $\mathrm{C} 677 \mathrm{~T}$ variant of the MTHFR gene.

Migraine can be a risk factor for ischaemic stroke, which might be related to the paradoxical embolism due to the presence of $\mathrm{PFO}$, especially among patients with migraine with aura. Domitrz et al. [12] studied 62 patients with migraine with aura, 60 patients with migraine without aura, and 65 healthy volunteers, and noted that $\mathrm{PFO}$ was much more prevalent among patients with migraine with aura (53\%) than in patients with migraine without aura $(25 \%)$ or in healthy subjects $(25 \%)$.

Rigatelli [29] reviewed papers published between 1988 and 2008, related to migraine and PFO, and concluded that a high proportion of subjects with $\mathrm{PFO}$ suffer from migraine, especially from migraine with aura, and these are persons with an increased risk of paradoxical embolism. The current study showed that PFO was more commonly found in patients with migraine with aura who had the C677T variant of the MTHFR gene. This finding should be replicated in a larger group of patients but it may suggest an association between migraine with aura and $\mathrm{PFO}$, as well as a possible common genetic background for both these conditions.

It is suggested that patients with migraine with aura more often have white matter lesions found in MRI. Recent studies show, however, that an association between paradoxical embolism and lesions seen in MRI is rather unlikely. Italian authors analysed the possible relationship between PFO-related shunt and white matter lesions in 87 patients with migraine with aura. The presence of shunt was noted in $45 \%$ of patients, but subjects with or without shunt did not differ regarding the number and size of lesions detected in MRI [30]. The same findings were reported by Bosca et al. [31], who did not find an association between vascular lesions seen in MRI and presence of the C677T variant of the MTHFR gene.

\section{Preliminary conclusions}

1. Frequency of the C677T variant of the MTHFR gene was similar in patients and controls, which seems to confirm the results of other authors. 
2. Significantly higher prevalence of $\mathrm{PFO}$ in patients with migraine with aura (with homozygous recessive genotype of $M T H F R$ ) might suggest their common genetic basis.

3. Hyperhomocysteinaemia was significantly more frequent in migraine patients with the $\mathrm{C} 677 \mathrm{~T}$ variant, which could be an additional risk factor of this disease.

\section{Acknowledgement}

This project was supported by the Medical University of Silesia (grant no. KNW-2-164/09).

\section{Disclosure}

Authors report no conflict of interest.

\section{References}

1. Nowakowski T., Jagustyn P., Maksymiuk G. Migrena - implikacje patofizjologiczno-terapeutyczne. Pol Przegl Med Lotn 2007; 1: 85-94.

2. Lea R.L., Ovaric M., Sundholm J., et al. The methylenotetrahydrofolate reductase gene variant $\mathrm{C} 677 \mathrm{~T}$ influences susceptibility to migraine with aura. BMC Medicine 2004; 2: 3 .

3. Oterino A., Valle N., Bravo Y., et al. MTHFR T677 homozygosis influences the presence of aura in migreneurs. Cephalgia 2004; 24: 491-494.

4. Schürks M., Rist P.M., Kurth T. MTHFR 677C $>$ T and ACE $\mathrm{D} / \mathrm{I}$ polymorphisms in migraine: a systematic review and metaanalysis. Headache 2010; 50: 588-599.

5. Wichlińska-Lipka M., Nyka W.M. Rola homocysteiny w patogenezie chorób układu nerwowego. Forum Med Rodz 2008; 2 223-228.

6. Piechowski-Jóźwiak B., Kwieciński H. Rola drożnego otworu owalnego w patogenezie udaru niedokrwiennego. Kardiologia po Dyplomie 2005; 3: 26-28.

7. Headache Classification Committee of the International Headache Society. Classification and diagnostic criteria for headache disorders, cranial neuralgias, and facial pain, 2nd edition. Cephalalgia 2004; 24: 1-160.

8. Kowa H., Yasui K., Takeshima T., et al. The homozygous C677T mutation in the methylenetetrahydrofolate reductase gene is a genetic risk factor for migraine. Am J Med Genet 2000; 96: 762-764

9. Marcus H.S., Harrison M. Estimation of cerebrovascular reactivity using transcranial doppler, including the use of breathholding as the vasodilatory stimulus. Stroke 1992; 23: 669-673.

10. Jauss M., Zanette E. Detection of right-to-left shunt with ultrasound contrast agent and transcranial Doppler sonography. Cerebrovasc Dis 2000; 10: 490-496.

11. Kozera G., Nyka W. Próba TCD na PFO - znaczenie kliniczne i ograniczenia. Pol Przegl Neurol 2004; 4 (supl. A): 58-59.
12. Domitrz I., Mieszkowski J., Kwieciński H. Występowanie drożnego otworu owalnego u pacjentów z migreną. Neurol Neurochir Pol 2004; 38: 89-92.

13. Tietjen E.G. Migraine and ischaemic heart disease and stroke: potential mechanisms and treatment implications. Cephalgia 2007; 27: 981-987.

14. de Tommaso M., Difruscolo O., Sardaro M., et al. Influence of MTHFR genotype on contingent negative variation and MRI abnormalities in migraine. Headache 2007; 47: 253-265.

15. Pezzini A., Grassi M., Del Zotto E., et al. Migraine mediates the influence of C667T MTHFR genotypes on ischemic stroke risk with a stroke-subtype effect. Stroke 2007; 38: 3145-3151.

16. Schürks M., Zee R.Y., Buring J.E., et al. Interrelationships among the MTHFR $677 \mathrm{C}>\mathrm{T}$ polymorphism, migraine, and cardiovascular disease. Neurology 2008; 71: 505-513.

17. Ferro A., Castro M.J., Lemos C., et al. The C677T polymorphism in MTHFR is not associated with migraine in Portugal. Dis Markers 2008; 25: 107-113.

18. Bottini F., Celle M.E., Calevo M.G., et al. Metabolic and genetic risk factors for migraine in children. Cephalgia 2006; 26: 731-737.

19. Kara I., Sazci A., Ergul E., et al. Association of the C677T and A1298C polymorphisms in the 5,10 methylenetetrahydrofolate reductase gene in patients with migraine risk. Brain Res $\mathrm{Mol}$ Brain Res 2003; 111: 84-90.

20. Kaunisto M.A., Kallela M., Hamalainen E., et al. Testing of variants of the MTHFR and ESR1 genes in 1798 Finnish individuals fails to confirm the association with migraine with aura. Cephalalgia 2006; 26: 1462-1472.

21. Oterino A., Valle N., Pasqual J., et al. Thymidylate synthase promoter tandem repeat and MTHFD1 R 653Q polymorphisms modulate the risk for migraine conferred by the MTHFR T677 allele. Brain Res Mol Brain Res 2005; 139: 163168.

22. Scher A., Terwindt G.M., Verschuren W.M., et al. Me and MTHFR C677T genotype in population-based sample. Ann Neurol 2006; 59: 372-375

23. Todt U., Freundenberg J., Goebel I., et al. MTHFR C677T polymorphism and migraine with aura. Ann Neurol 2006; 60: 621-622.

24. Liu A., Menon S., Colson N.J., et al. Analysis of the MTHFR C677T variant with migraine phenotypes. BMC Res Notes 2010; 28: 213 .

25. Schürks M., Rist P.M., Kurth T. MTHFR 677C $>$ T and ACE $\mathrm{D} / \mathrm{I}$ polymorphisms in migraine. A systematic review and metaanalysis. Headache 2010; 50: 588-599.

26. Lea R., Colson N., Quinlan S., et al. The effects of vitamin supplementation and MTHFR(C677T) genotype on homocysteine-lowering and migraine disability. Pharmacogenet Genomics 2009; 19: 422-428.

27. Hering Hanit R., Gadoth N., Yavetz A., et al. Is blood homocysteine elevated in migraine? Headache 2001; 41: 779-781.

28. Oterino A., Toriello M., Valle N., et al. The relationship between homocysteine and genes of folate-related enzymes in migraine patients. Headache 2010; 50: 99-168.

29. Rigatelli G. Migraine and patent foramen ovale: connecting flight or one way ticket? Expert Rev Neurother 2008; 8: 1331-1337. 
30. Del Sette M., Dinia L., Bonanzo L., et al. White matter lesions in migraine and right-to-left shunt: a conventional and diffusion MRI study. Cephalalgia 2008; 28: 376-382.

31. Bosca M., Tembl J., Bosca I., et al. Estudio de la relacion entre lesiones de sustancia blanca en la resonancia magnetica y foramen oval permeable en pacientes con migrana. Neurologia 2008; 23: 499-502. 